\title{
Long-term effects of exposure of pancreatic islets to nicotinamide in vitro on DNA synthesis, metabolism and B-cell function
}

\author{
S. Sandler and A. Andersson \\ Department of Medical Cell Biology, Uppsala University, Uppsala, Sweden
}

\begin{abstract}
Summary. Using ${ }^{3} \mathrm{H}$-thymidine labeling techniques, we found that rates of DNA synthesis in islet cells doubled when mouse pancreatic islets were cultured for 1 week with $10 \mathrm{mmol} / 1 \mathrm{ni}-$ cotinamide, a potent poly(ADP-ribose) synthetase inhibitor. Culture with nicotinamide partially inhibited glucose-stimulated insulin release, whereas the islet insulin content and rate of (pro)insulin biosynthesis remained unchanged. Long-term exposure to nicotinamide decreased glucose oxidation and
\end{abstract}

ATP content in the islets. The findings support the view that poly(ADP-ribose)synthetase inhibitors stimulate islet cell replication, but may be accompanied by significant inhibitory effects on islet cell function.

Key words: Autoradiography, insulin release, DNA synthesis, nicotinamide, pancreatic islets, poly(ADP-ribose), synthetase.
Poly(ADP-ribose)synthetase is a chromatin-associated enzyme which is involved in cellular DNA repair [1] and differentiation [2-4]. In pancreatic islets the activity of this enzyme increases upon exposure to streptozotocin, leading to cytotoxic cellular NAD depletion $[5,6]$ coupled to increased DNA repair synthesis $[7,8]$. The B-cytotoxic effects of streptozotocin can be counteracted by inhibitors of poly(ADP-ribose) synthetase such as nicotinamide and 3 -aminobenzamide $[5,6,9,10]$. It was recently demonstrated that such compounds may also induce B-cell regeneration in diabetic animals [11]. Okamoto [12] postulated that the poly(ADP-ribose) synthetase inhibitors may counteract a suppression of B-cell DNA replication, thus inducing B-cell regeneration. An increased knowledge on how the B-cell growth is regulated is warranted. Such information may point towards new approaches in the treatment of Type 1 (insulin-dependent) diabetes mellitus, i.e. administration of drugs which induce B-cell regeneration by affecting the nuclear control of DNA replication.

The aim of the present investigation was to study the long-term effects of a potent poly(ADP-ribose) synthetase inhibitor, nicotinamide, on islet cells in vitro. The effects of nicotinamide on islet cell DNA synthesis were determined by ${ }^{3} \mathrm{H}$-thymidine labeling, and those on islet metabolism by measuring glucose oxidation and the contents of adenine and pyridine nucleotides. Specific B-cell functions were monitored by assaying glucosestimulated insulin release and (pro)insulin biosynthesis.

\section{Materials and methods}

\section{Islet preparation and culture}

Pancreatic islets were isolated from adult NMRI mice by a collagenase isolation technique [13]. The islets were cultured free-floating for 7 days at $37{ }^{\circ} \mathrm{C}$ in medium RPMI 1640 (11.1 mmol/1 glucose) supplemented with $10 \%$ calf serum, in an atmosphere of humidified air $+5 \% \mathrm{CO}_{2}[14]$, with or without the addition of $10 \mathrm{mmol} / 1$ nicotinamide. The culture medium was changed every second day.

\section{DNA synthesis and content}

For estimation of islet DNA synthesis, $1 \mu \mathrm{Ci} / \mathrm{ml}$ of [methyl- $\left.{ }^{-3} \mathrm{H}\right]$ thymidine (Amersham International, Amersham, UK) was added to the culture medium on day 6 . After $18 \mathrm{~h}$, duplicate groups of 50 islets were washed in Hanks' solution containing $10 \mathrm{mmol} / 1$ thymidine and disrupted ultrasonically in redistilled water. Duplicate aliquots of the homogenates were precipitated with $5 \%(\mathrm{w} / \mathrm{v})$ trichloroacetic acid, and the labeled DNA was separated from unbound ${ }^{3} \mathrm{H}$-thymidine by filtering through glass microfibre filters $(\mathrm{GF} / \mathrm{A} 2.5 \mathrm{~cm}$; Whatman, $\mathrm{UK}$ ). After drying, the radioactivity on the filters was determined by liquid scintillation. In another sample of the homogenate, the islet DNA content was determined $[15,16]$. From the dishes of islets exposed to ${ }^{3} \mathrm{H}$-thymidine, a group of about 50 islets was harvested and washed as above; after fixation in Bouin's solution, these islets were processed for autoradiography for calculation of the islet cell labeling index [17]. Labeled islet cells were identified, and at least 800 cells were scored to calculate the labeling index in each group of cultured islets.

\section{(Pro)insulin and total protein biosynthesis}

Groups of 10 islets were incubated at $37{ }^{\circ} \mathrm{C}$ for $2 \mathrm{~h}$ (air $+5 \% \mathrm{CO}_{2}$ ) in a bicarbonate buffer [18] containing $10 \mathrm{mmol} / 1$ Hepes and $2 \mathrm{mg} / \mathrm{ml}$ al- 
Table 1. DNA content, DNA synthesis and autoradiographic labeling index of mouse pancreatic islets cultured for 1 week in medium RPMI 1640 with or without addition of $10 \mathrm{mmol} / 1$ nicotinamide

\begin{tabular}{lll}
\hline & Controls & $\begin{array}{c}+10 \text { mmol/1 } \\
\text { nicotinamide }\end{array}$ \\
\hline $\begin{array}{c}\text { DNA content } \\
(\mu \mathrm{g} / 10 \text { islets })\end{array}$ & $0.32 \pm 0.043(14)$ & $0.34 \pm 0.034(14)$ \\
$\begin{array}{c}\text { DNA synthesis } \\
\left(\mathrm{dpm} \times 10^{-2} / 10 \text { islets }\right)\end{array}$ & $3.6 \pm 0.34(9)$ & $5.7 \pm 0.34 \quad(9)^{\mathrm{a}}$ \\
$\begin{array}{c}\text { Autoradiographic islet } \\
\text { cell labeling index }(\%)\end{array}$ & $2.3 \pm 0.44(9)$ & $4.6 \pm 0.26 \quad(9)^{\mathrm{a}}$ \\
\hline
\end{tabular}

Values are given as means \pm SEM with numbers of culture experiments within parentheses.

${ }^{a} p<0.001$, unpaired Student's t-test.

Table 2. (Pro)insulin and total protein biosynthesis, insulin content and insulin release, and glucose oxidation in mouse pancreatic islets cultured for 1 week in medium RPMI 1640 with or without addition of $10 \mathrm{mmol} / 1$ nicotinamide

\begin{tabular}{|c|c|c|}
\hline & Controls & $\begin{array}{l}+10 \mathrm{mmol} / 1 \\
\text { nicotinamide }\end{array}$ \\
\hline $\begin{array}{l}\text { (Pro)insulin biosynthesis } \\
\quad\left(\mathrm{dpm} \times 10^{-3} / 10 \text { islets } \times 2 \mathrm{~h}\right)\end{array}$ & $34.2 \pm 5.5 \quad(10)$ & $35.9 \pm 5.5 \quad(10)$ \\
\hline $\begin{array}{l}\text { Total protein biosynthesis } \\
\left(\mathrm{dpm} \times 10^{-3} / 10 \text { islets } \times 2 \mathrm{~h}\right)\end{array}$ & $130 \pm 17.7$ & $147 \pm 18.2$ \\
\hline $\begin{array}{l}\text { Fraction (pro)insulin of total } \\
\text { protein biosynthesis (\%) }\end{array}$ & $25.7 \pm 1.0$ & $24.0 \pm 0.65(10)$ \\
\hline $\begin{array}{l}\text { Insulin content } \\
\text { (ng/10 islets) }\end{array}$ & $427 \pm 45.6$ & $352 \pm 45.6$ \\
\hline \multicolumn{3}{|l|}{$\begin{array}{l}\text { Insulin release } \\
\quad(\mathrm{ng} / 10 \text { islets } \times 1 \mathrm{~h})\end{array}$} \\
\hline $1.67 \mathrm{mmol} / 1$ glucose & $4.1 \pm 0.67(22)$ & $4.2 \pm 0.76(22)$ \\
\hline $16.7 \mathrm{mmol} / 1$ glucose & $44 \pm 6.7$ & $24 \pm 3.3(22)^{\mathrm{a}}$ \\
\hline $\begin{array}{l}\text { Glucose oxidation } \\
\text { (pmol glucose } / 10 \text { islets } \\
\times 90 \text { min) }\end{array}$ & $525 \pm 25.7$ & $446 \pm 37.4(11)^{\mathrm{b}}$ \\
\hline
\end{tabular}

Values are given as means \pm SEM with numbers of culture experiments within parentheses.

${ }^{\mathrm{a}} p<0.02$, Student's unpaired $\mathrm{t}$-test; ${ }^{\mathrm{b}} p<0.05$, Student's paired t-test

Table 3. Adenine nucleotide (AMP + ADP + ATP) and pyridine nucleotide (NADH + NAD) contents of mouse pancreatic islets cultured for one week in medium RPMI 1640 with or without addition of $10 \mathrm{mmol} / \mathrm{l}$ nicotinamide

\begin{tabular}{lllllll}
\hline & \multicolumn{1}{c}{ Controls } & \multicolumn{3}{c}{$\begin{array}{c}+10 \mathrm{mmol} / 1 \\
\text { nicotinamide }\end{array}$} \\
\hline $\begin{array}{l}\text { AMP+ADP+ATP content } \\
\text { (pmol/islet) }\end{array}$ & 7.4 & \pm 0.44 & $(15)$ & 6.2 & \pm 0.44 & $(16)$ \\
$\begin{array}{l}\text { ATP content } \\
(\mathrm{pmol} / \text { islet })\end{array}$ & 4.2 & \pm 0.18 & $(15)$ & 3.3 & $\pm 0.24 \quad(16)^{\mathrm{a}}$ \\
$\begin{array}{l}\text { NADH + NAD content } \\
(\mathrm{pmol} / 10 \text { islets })\end{array}$ & 5.0 & \pm 0.30 & $(16)$ & 6.0 & $\pm 0.34 \quad(16)^{\mathrm{a}}$ \\
\begin{tabular}{l} 
NADH/NAD \\
\hline
\end{tabular} & $0.106 \pm 0.013(16)$ & $0.112 \pm 0.021(16)$ \\
\hline
\end{tabular}

Values are given as means \pm SEM with numbers of culture experiments within parentheses.

${ }^{\mathrm{a}}$ and ${ }^{\mathrm{b}}$ denote $p<0.05$, Student's unpaired and paired t-test respectively bumin, hereafter referred to as $\mathrm{KRBH}, 16.7 \mathrm{mmol} / 1$ glucose and $50 \mu \mathrm{Ci} / \mathrm{ml} \mathrm{L}-\left[4.5-{ }^{3} \mathrm{H}\right]$ leucine (Amersham). After the incubation the islets were washed and homogenised, and the biosynthesis of total protein and (pro)insulin was measured [19].

\section{Insulin release and content}

Triplicate groups of 10 islets were incubated for $1 \mathrm{~h}$ in $250 \mu \mathrm{l}$ of $\mathrm{KRBH}$ containing $1.67 \mathrm{mmol} / \mathrm{l}$ glucose $\left(37^{\circ} \mathrm{C} ; \mathrm{CO}_{2} / \mathrm{O}_{2}: 5 / 95\right)$. The medium was then replaced by $\mathrm{KRBH}$ supplemented with $16.7 \mathrm{mmol} / 1$ glucose for another $1-\mathrm{h}$ period. Insulin released to the media was determined by radioimmunoassay [20]. Insulin content was measured after extraction of the islets overnight at $+4{ }^{\circ} \mathrm{C}$ in acid ethanol $(0.18 \mathrm{M} \mathrm{HCl}$ in $70 \%(\mathrm{v} / \mathrm{v})$ ethanol).

\section{Glucose oxidation}

The procedure has been described previously [21]. Groups of 10 islets in triplicate were incubated for $90 \mathrm{~min}$ in $100 \mu \mathrm{l}$ of $\mathrm{KRBH}$ containing $\mathrm{D}-\left(\mathrm{U} \cdot{ }^{14} \mathrm{C}\right)$ glucose (Amersham) and non-radioactive glucose to give a final concentration of $16.7 \mathrm{mmol} / 1$ and a specific radioactivity of $0.5 \mathrm{mCi} / \mathrm{mmol}$

\section{Adenine and pyridine nucleotide contents}

Cultured islets in groups of 10 or 30 were transferred to plastic tubes containing $0.1 \mathrm{ml}$ of $\mathrm{KRBH}$ plus $11.1 \mathrm{mmol} / 1$ glucose with or without $10 \mathrm{mmol} / 1$ nicotinamide. The tubes were incubated for $60 \mathrm{~min}$ at $37^{\circ} \mathrm{C}$ (air $+5 \% \mathrm{Co}_{2}$ ), and the incubation media were then rapidly withdrawn and exchanged for $40 \mu \mathrm{l}$ of $0.02 \mathrm{~mol} / 1 \mathrm{NaOH}$ (adenine nucleotides) or $30 \mu \mathrm{l}$ of $0.04 \mathrm{~mol} / 1 \mathrm{NaOH}$ (pyridine nucleotides) and instantly frozen in liquid nitrogen. The islet contents of ATP + ADP + AMP and NADH + NAD were measured by bioluminescence methods [22] as described previously [9].

\section{Statistical analysis}

Data were computed as means \pm SEM, and compared using the Student's t-test for unpaired samples. Levels of significance are as shown in Tables 1-3.

\section{Results}

Tissue culture of isolated islets in the presence of $10 \mathrm{mmol} / 1$ nicotinamide increased ${ }^{3} \mathrm{H}$-thymidine incorporation by about $60 \%$ (Table 1 ). The possibility that this increase was due to enhancement of islet cell DNA synthesis was supported by the finding that the autoradiographic islet cell labeling index was doubled. Furthermore, there was a significant correlation between the rates of DNA synthesis in the islets and their labeling index $(r=0.69, p<0.01, n=18)$. The increased DNA replication in the islets cultured with nicotinamide was not, however, accompanied by a net increase in the islet content of DNA (Table 1).

Culture in the presence of $10 \mathrm{mmol} / 1$ nicotinamide did not affect either the rates of (pro)insulin and total protein biosynthesis or the islet insulin content (Table 2). Glucose-stimulated insulin release was reduced, however, by about $50 \%$ in islets cultured in the nicotinamide-supplemented medium. Likewise, the rate of glucose oxidation in the islets was slightly inhibited 
(Table 2). In acute experiments with freshly isolated islets, the presence of $10 \mathrm{mmol} / 1$ nicotinamide did not influence the islet glucose oxidation rate (data not shown). There was no difference in the total content of adenine nucleotides between islets cultured in the presence and absence of nicotinamide, but the content of ATP was reduced in the former islets (Table 3 ). It was also found that the total islet content of NADH + NAD was increased by about $20 \%$ in the experimental group, but the redox state as reflected by the NADH/NAD ratio was unaltered.

\section{Discussion}

The present study shows that long-term exposure of isolated pancreatic islets to nicotinamide in vitro at a concentration which inhibits the poly(ADP-ribose) synthetase activity by about $90 \%$ [10] has a number of effects on the islets. The observation of a nicotinamide-induced increase of the islet DNA synthesis as measured by incorporation of ${ }^{3} \mathrm{H}$-thymidine cannot be explained by an effect on the intracellular thymidine pool. Thus, the number of grains covering the labelled cells in the autoradiographs was very high in both experimental groups and well above the number defined to constitute a labelled cell ( $>15$ grains/cell). The increased DNA replication in the islet cells found in this study supports the in vivo findings by Yonemura et al. [11]. However, these authors also observed enlargement of the islets in animals treated with poly(ADP-ribose) synthetase inhibitors, whereas in the present experiments we failed to demonstrate an elevated DNA content of the mouse islets cultured with nicotinamide. Enhanced DNA synthesis in the islet cells without an accompanying increase in their total DNA content has been reported after islet culture with 3-isobutyl-1-methylxanthine [23]. This phenomenon may suggest a loss of cells in vitro of sufficient magnitude to prevent a net growth of the islets. It should also be noted that in the study by Yonemura et al. (1984) the animals were hyperglycaemic and a growth of the islet mass could well be supported by a high glucose concentration.

The impairment of glucose-stimulated insulin release from the islets cultured with nicotinamide is obscure. A reduction of ATP in the B cells, which is required for the energy-dependent process of insulin secretion, may contribute to this impairment. However, it was not evaluated in this investigation if the islets cultured with nicotinamide are able to increase their generation of ATP in response to a high glucose concentration. On the other hand, the biosynthesis of both total protein and (pro)insulin was intact, despite the disturbance in oxidative metabolism. The most probable reason for net increase in islet NADH + NAD content after culture with nicotinamide is that nicotinamide had been metabolized as a precursor of NAD synthesis. The observed reduction in islet ATP is in accordance with the finding by Hoshino et al. [24] that ATP was decreased in liver cells cultured with nicotinamide. To what extent the long-term effect of nicotinamide on islet glucose oxidation reflects an inhibition of poly(ADP-ribose) synthetase is unclear, and obviously this impairment has to be induced over a prolonged period. Thus, we observed no acute effects of nicotinamide on islet glucose oxidation and previously demonstrated a lack of effect on (pro)insulin biosynthesis, oxygen uptake, and adenine and pyridine contents in islet cells [9]. Similarly, Zawalich et al. [25] found that nicotinamide did not affect islet glucose utilization. In their study, however, nicotinamide potentiated glucose-stimulated insulin release, in contrast to the long-term inhibitory effect shown in this study. In conclusion, the present investigation supports the view that poly(ADP-ribose) synthetase inhibitors can stimulate the generation of new islet cells. It is clear that nicotinamide exerts several effects which may well be separated from an inhibition of poly(ADP-ribose) synthesis. As pointed out by Milam and Cleaver [26], such other effects on metabolic processes emphasize the risks of attributing data obtained by using poly(ADP-ribose) synthetase inhibitors to reductions of poly(ADP-ribose) concentrations alone.

Acknowledgements. We thank E. Forsbeck, A. Nordin and P. Wentzel for skilful technical assistance and L. Bryngelsson and A. Snellman for preparation of the manuscript. This study was supported by grants from the Swedish Medical Research Council (K86-12P-7680-01;12X109), the Swedish Diabetes Association, the Juvenile Diabetes Foundation International, the Nordic Insulin Fund, Sykonen Svenssons Fond, the Clas Groschinsky Memorial Foundation, the Åke Wiberg Foundation and the Swedish Society of Medicine.

\section{References}

1. Berger NA (1985) Poly(ADP-ribose) in the cellular response to DNA damage. Radiat Res 101: 4-15

2. Caplan AI, Rosenberg MJ (1975) Interrelationship between poly (ADP-rib) synthesis, intracellular NAD levels and muscle or cartilage differentiation from mesodermal cells of embryonic chich limb. Proc Natl Acad Sci USA 72: 5 1852-1857

3. Pekala PH, Lane MD, Watkins PA, Moss J (1981) On the mechanism of preadipocyte differentiation: Masking of poly(ADPribose) synthetase activity during differentiation of 3T3-L1 preadipocytes. J Biol Chem 256: 4871-4876

4. Kanai M, Miwa M, Kondo T, Tanaka Y, Nakayasu M, Sugimura T (1982) Involvement of poly(ADP-ribose) metabolism in induction of differentiation of HL-60 promyelocytic leucemia cells. Biochem Biophys Res Commun 105: 404-411

5. Yamamoto H, Uchigata $Y$, Okamoto $H$ (1981) Streptozotocin and alloxan induce DNA strand breaks and poly(ADP-ribose) synthetase in pancreatic islets. Nature 294: 284-286

6. Uchigata Y, Yamamoto H, Nagai H, Okamoto H (1983) Effect of poly(ADP-ribose) synthetase inhibitor administration to rats before and after injection of alloxan and streptozotocin on islet proinsulin synthesis. Diabetes 32: 316-318

7. Sandler S, Swenne I (1983) Streptozotocin, but not alloxan, induces DNA repair synthesis in mouse pancreatic islets in vitro. Diabetologia 25: 444-447

8. Sandler S, Swenne I (1985) DNA repair synthesis in the pancreatic islets of streptozotocin-treated mice. Diabetes Res 2: 255-258 
9. Sandler S, Welsh M, Andersson A (1983) Streptozotocin-induced impairment of islet B-cell metabolism and its prevention by a hydroxyl radical scavenger and inhibitors of poly(ADP-ribose) synthetase. Acta Pharmacol Toxicol 53: 392-400

10. Wilson GL, Patton NJ, McCord JM, Mullins DW, Mossman BT (1984) Mechanisms of streptozotocin- and alloxan-induced damage in rat B cells. Diabetologia 27: 587-591

11. Yonemura $Y$, Takashima T, Miwa K, Miyazaki I, Yamamoto $H$, Okamoto $\mathrm{H}$ (1984) Amelioration of diabetes mellitus in partially depancreatized rats by poly(ADP-ribose) synthetase inhibitors. Evidence of islet B-cell regeneration. Diabetes 33: 401-404

12. Okamoto H (1984) Molecular basis of experimental diabetes: Degeneration, oncogenesis and regeneration of pancreatic B-cells of islets of Langerhans. Bioessays 2: 15-21

13. Howell SL, Taylor KW (1968) Potassium ions and the secretion of insulin by islets of Langerhans incubated in vitro. Biochem $\mathrm{J} 108$ : $17-24$

14. Andersson A (1978) Isolated mouse pancreatic islets in culture: Effects of serum and different culture media on the insulin production of the islets. Diabetologia 14: 397-404

15. Kissane JM, Robins E (1958) The fluoremetric measurement of deoxyribonucleic acid in animal tissues with special reference to the central nervous system. J Biol Chem 233: 184-188

16. Hinegardner RT (1971) An improved fluorometric assay for DNA. Anal Biochem 39: 197-201

17. Swenne I, Andersson A (1984) Effect of genetic background on the capacity for islet cell replication in mice. Diabetologia 27 : 464-467

18. Krebs HA, Henseleit K (1932) Untersuchungen über die Harnstoffbildung im Tierkörper. Hoppe-Seylers Z physiol Chem 210: 33-36

19. Berne C (1975) Anti-insulin serum coupled to Sepahrose 4B as a tool for the investigation of insulin biosynthesis in the B-cells of obese hyperglycemic mice. Endocrinology 97:1241-1247

20. Heding LG (1972) Determination of total serum insulin (IRI) in insulin-treated patients. Diabetologia 8: 260-266

21. Andersson A (1974) Long-term effects of glucose on insulin release and glucose oxidation by mouse pancreatic islets maintained in tissue culture. Biochem J 140: 377-382

22. Brolin SE, Ågren A (1981) Potentialities of bioluminescence analyses in research on the pancreatic islets. Upsala J Med Sci 86: $125-130$

23. Nielsen JH (1985) Dissociation between insulin secretion and DNA synthesis in cultured pancreatic islets. Biomed Biochim Acta $44: 161-166$

24. Hoshino J, Schlüter U, Kröger H (1984) Nicotinamide methylation and its relation to NAD synthesis in rat liver synthesis. Biochemical basis for the physiological activities of 1-methylnicotinamide. Biochim Biophys Acta 801: 250-258

25. Zawalich WS, Dye ES, Matschinsky FM (1979) Nicotinamide modulation of rat islet cell responsivness in vitro. Horm Metab Res 11: 469-471

26. Milam KY, Cleaver JE (1984) Inhibitors of poly(Adenosine Diphosphate-Ribose) synthesis: Effect on other metabolic processes. Science 223: 589-591

Received: 24 October 1985

and in revised form: 23 December 1985

Dr Stellan Sandler

Dept of Medical Cell Biology

P.O. Box 571

S-75123 Uppsala

Sweden 